\title{
The Effect Transparency, Accountability, Responsibility, Independency and Fairness on the Governance Performance of State Universities in Indonesia
}

\author{
Ismet Sulila (Corresponding author) \\ Public Administration Study Program, Gorontalo State University \\ Jenderal Sudirman Street, No. 06, Gorontalo, Indonesia
}

Received: Jan. 22, 2022 Accepted: Feb. 22, 2022 Online published: Feb. 25, 2022

doi:10.5296/jpag.v12i1.19493ＵRL: https://doi.org/10.5296/jpag.v12i1.19493

\begin{abstract}
The universities' high and low competitiveness in Indonesia is inseparable from the low quality of services and the management or governance in universities. As a public institution, a university or higher education has an obligation to carry out public services in the fields of education, research, and community service. To achieve superiority and good competitiveness, the university governance in Indonesia can be observable from the Key Performance Indicator. Besides, the implementation of the three pillars of higher education through the achievement of the key performance indicator results in the performance of good university governance. To achieve good governance performance, thus; transparency, accountability, responsibility, independency, and fairness are required. This present study aimed to reveal the effect of transparency, accountability, responsiveness, independency, and fairness on the governance performance of universities in Indonesia. At the same time, this study relied on the ex post facto research method. The findings based on partial and simultaneous testing depicted that the factors of transparency, accountability, responsibility, independency, and fairness positively and significantly affect the governance performance of state universities at Universitas Negeri Gorontalo.
\end{abstract}

Keywords: good university governance and performance

\section{Introduction}

Higher education institutions in Indonesia are expected to be able to compete at the national, regional, and international levels. This competition can be carried out if each university is able to respond to rapid environmental changes and satisfy the desires of customers, namely students, government, business, and industry, as well as society in general. Most importantly, changes and focus on sustainable competitive advantage require powerful people with the 
potential and capital both independently and organizationally, able and eager to carry out work intelligently, competitively, and cooperatively for the benefit and progress of higher education. (Aghion et al., 2010). Additionally, university governance can provide academic and scientific freedom for the academic community so that they are able to develop optimally to become outstanding academics and scientists (Lokuwaduge \& Armstrong, 2015). In this case, the concept of higher education autonomy is highly correlated with quality assurance of the learning process and its products in order to meet the accountability of higher education to stakeholders.

Referring to Law No. 12 of 2012 concerning Higher Education, the components that constitute the performance of higher education institutions include main and supporting components. In detail, the main components are as follows: 1) learning process, 2) curriculum, 3) lecturers, 4) learning facilities, 5) funding, and 6) research. In comparison, the supporting components are management and leadership. (Nandi, 2021) argues that the embodiment of governance performance requires universities to have clear planning and implementation, starting from the formulation of the vision, mission, goals, and objectives, as well as strategies for achieving them. Universities also entail effective governance, leadership, management systems, and quality assurance. Thereunto, the universities' concern to components of students' and graduates' is vital in achieving an effective learning process and maintaining graduates' quality (Muhsin et al., 2020). Equally important, human resources, i.e., lecturers and other education personnel, are a prominent element for universities to increase the institutional capacity as a whole. Other important elements that universities need to pay attention to are the curriculum, learning process, and academic atmosphere. All of the above components are certainly supported by aspects of financing, facilities, and infrastructure, as well as an adequate information system. All of this is also realized because higher education can enhance the nation's competitiveness in facing globalization, develop science and technology, and generate intellectuals and professional scientists who are cultured, creative, tolerant, democratic, and have a tough character. (Ansari \& AG, 2019).

According to (Irianto, 2012), a good university is required to have certainty about governance. Autonomous universities are required to have certainty about GUG (Good University Governance). Accountability in the form of transparency of checks and balances must be the soul of the governance (Siambi, 2021). There must be an orderly organization that is able to account for every penny at the university. Apart from that, the relevance of financial with the academic activities can be justified. Besides that, it is also imperative for universities to further improve their governance (Abdul \& Adam, 2018); (Reschiwati et al., 2021); (Rulyanti Susi Wardhani et al., 2019). (Wahyudin et al., 2017) state that higher educations that can implement good governance will increase their management performance. This is also in line with (Sagara \& Yustini, 2019), who assert that the low quality of higher education in Indonesia is caused by the government's low commitment to education (Mahmoud et al., 2017), leadership, and unimplemented good university governance. At the same time, (Sayidah et al., 2019) declare that State Universities in Indonesia experienced a decline in quality, do not contribute to the nation's development, and lag behind universities in other countries. In addition to limited funding, the leading cause is the higher education 
management system and organization which is considered unhealthy and centralized.

Moreover, (Suyahman, 2016) pinpointed several weaknesses that occur in universities in Indonesia, including 1) Unhealthy organizations; characterized by low quality, education (academic) is often irrelevant. 2) State universities abbreviated as PTN, is part of the government bureaucracy; so that they are powerless, slow, and often intervened, 3) State universities is only responsible to their direct superiors, not to stakeholders, and 4) the initiative always comes from outside (in the form of instructions). In the meantime, college or university governance is vital, especially in this modern era. Each university of higher education institution has its own profile, and when we look at the profile, there are always advantages and achievements that have been achieved. Whereas, universities with high quality are inseparable from good governance. Theoretically, the principles of Good University Governance will affect the governance performance of universities. The principles of Good University Governance are 1) Transparency. Transparency discusses the extent to which the university's regulatory policies, programs, activities, and budgets are known and understood by the academic community so that they can actively participate. This transparency principle can be associated with legal and regulatory policies, the use of financial and non-financial resources, and reporting systems using various media that can be reached by all stakeholders (Jongbloed et al., 2018). Specifically, the form of transparency can be perceptible in terms of leadership decision-making, new student admissions, recruitment and acceptance of lecturers and education staff, as well as the use of higher education funding sources that must be accessible to the general public. 2). Accountability. Accountability discusses how far higher education leaders' level of accountability in carrying out their duties. The principle of accountability is more reliable to the responsibility of an institution to the policy rules that the institution has decided. This emphasizes more on the obedience of all personnel in higher education institutions in complying with and carrying out all policies and rules that have bound them in an institution. (Darmawan, 2019). As has been stated by (Wahyudin et al., 2017), the method used by the institution to ensure accountability is by establishing an Internal Audit Agency and quality assurance. In terms of guaranteeing the financial management system and reporting, it is monitored by the Internal Audit Board, while for academics, quality assurance is consistently monitored to ensure quality.

3) Responsibility. Responsiveness relates to policies, regulations, and resources to obtain support and positive responses from the academic community. Responsibility is a principle that implies that an institution must comply with all regulations or rules from external parties (Julius \& Tierney, 2000); (Delgado, 2014). For instance, laws, government regulations, presidential decrees, ministerial regulations or ministerial decrees, and others. Therefore, higher education must follow these external parties' regulations in carrying out or performing their activities. Likewise, universities need to be responsive to adapt to environmental changes. This means that universities must be responsive to all stakeholder desires and respond to highly dynamic environmental changes. Thereby, every policy step made by the institution always pays attention to the desires of stakeholders. 4) Independence. The independence that is expected in this context is that in carrying out university governance responsibilities, it must be free from various interests (Sternberg, 2007). This is essential to 
ascertain that decision-making is done independently and free from the intervention of other parties so that it can be ensured that the decisions taken and implemented are genuinely for the performance of university governance. 5) Fairness. Fairness referred to in this case is that universities must be able to provide fair and proportional treatment to customers, namely students, lecturers, education staff, government, and the general public (Silvernail et al., 2021). This study seeks to investigate the effect of the principles of good university governance, namely transparency, accountability, responsiveness, independency, and fairness, on the governance performance of higher education in Indonesia.

\section{Method}

This study employed ex post facto research method. Ex post facto research means "from what is done after the fact" (Akmaliyah, 2013), so this research is also known as after the fact research. Thus, this research can only be carried out when an event in which there are components of the independent variable and the dependent variable has occurred. Universitas Negeri Gorontalo was selected as the research site due it complied with the research title and was highly relevant to the problem posed. Additionally, this study relied on a quantitative approach, namely research on data collected and expressed in the form of numbers, sometimes it also in the form of qualitative data to support it, such as words or sentences arranged in questionnaires, sentences resulting from consultations or interviews between researchers and informants. (Sugiyono, 2014) defines quantitative data are data in numbers or qualitative data that are numbered. Qualitative data that are numbered contain in a measurement scale.

Moreover, it applied a field study since the research only collects data, looks for facts, explains the data by collecting and compiling data, and then analyzing it based on the analytical model taken, afterward interpreting it based on the existing theoretical basis. The population in this study was 96 lecturers who also served as officials or had structural positions. At the same time, this study employed a total sampling technique, a sampling that uses all population members as a sample. This is often done when the population is relatively small, less than 100 people or research intends to make generalizations with minor errors. The total sample is also known as census, where all population members are used as a sample. Besides, data collection techniques used in this study were interviews, observation, questionnaires, and documentation.

\section{Results}

Generally, the principles of good university governance include transparency, accountability, responsiveness, responsibility, independency, and fairness. Those principles must be adopted by every higher education, which is then adapted to the conditions and existence within a regional boundary. For this reason, it must be supported by a set of rules, freedom of academic autonomy, good organizational culture, vision, strategy, excellent leadership team, transfer of technology, and qualified research output. Nevertheless, it is necessary to consider the resource budget, income, education costs, and research grants in the availability of resources. In addition, universities must also concentrate on talents or components that require qualified researchers as teachers, concerned about the graduates, and produce superior 
research. Establishing good university governance makes a higher education institution deliver good performance and conformity (Nisar, 2015; Belgaroui \& Hamad, 2021). This performance is expected to generate value creation, resource utilization, and conformity of accountability and assurance.

Furthermore, the principle of good governance on transparency means that a higher education institution makes decisions and implements decisions that must be open. Meanwhile, the principle of independence in good university governance emphasizes independence of an institution in managing higher education. This principle requires the existence of higher education autonomy. The autonomy of higher education institutions worldwide has different perceptions and interpretations. Similarly, implementing the principle of fairness is expected to provide a value of justice to all existing stakeholders. The principle of authority, consultation, and representation depicts that higher education or university is expected to have full authority that can be used to make decisions or policies. To make decisions requires apparent authority without interference from any party (Matei \& Iwinska, 2014).

Moreover, higher education is also required to be an institution for stakeholders as a place for consultations related to science and technology and must be able to represent all the vital interests. (Nurhikmayanti, 2017) suggests that new policies and paradigms of higher education management based on autonomy and organizational health need to be developed to increase the nation's competitiveness. Good university governance is an effort of universities to keep abreast of the times. Most importantly, standardization is a reference for all management carried out by universities. Hence, all universities must meet the predetermined standards in order to continue to maintain their existence (Arifudin, 2019).

\subsection{Partial Test}

The partial test results from hypothesis 1 to hypothesis 5 are presented in the following table:

Table 1. The Partial Effect

\begin{tabular}{|c|c|c|c|c|c|c|}
\hline \multirow{2}{*}{ Model } & \multicolumn{2}{|c|}{$\begin{array}{c}\text { Unstandardized } \\
\text { Coefficients }\end{array}$} & $\begin{array}{c}\text { Standardized } \\
\text { Coefficients }\end{array}$ & \multirow{2}{*}{ t } & \multirow{2}{*}{ Sig. } \\
\cline { 3 - 7 } \multicolumn{2}{|c|}{} & B & Std. Error & Beta & & \\
\hline \multirow{3}{*}{1} & (Constant) & -3.143 & 4.053 & & -.775 & .440 \\
\cline { 2 - 7 } & Transparency & .134 & .059 & .156 & 2.248 & .027 \\
\cline { 2 - 7 } & Accountability & .259 & .092 & .259 & 2.811 & .006 \\
\cline { 2 - 7 } & Responsibility & .350 & .093 & .320 & 3.757 & .000 \\
\cline { 2 - 7 } & Independency & .191 & .054 & .205 & 3.548 & .001 \\
\cline { 2 - 7 } & Fairness & .126 & .049 & .130 & 2.575 & .012 \\
\hline
\end{tabular}

Source: Data Processed by SPSS 21, 2020

Based on the table above, the following multiple regression equation can be formulated:

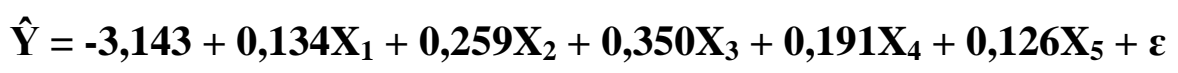

The equation obviously denotes that all variables have a positive elasticity value, which 
means that all variables are rational with a theory that becomes a reference where when an institution adheres to transparency, accountability, responsibility, independency, and fairness, it will give good results, indicated by the improvement of governance performance of state universities at Universitas Negeri Gorontalo. Further, a partial test is performed after the $\mathrm{t}$-table value has been determined first. The t-table value is 1,987 ( $\mathrm{df}=\mathrm{n}-\mathrm{k}-1=96-5-1$ =90). The more detailed results are observable from (1) The t-count value for transparency is 2.248 with a significance value lower than the probability value of 0.05 . Thus, the transparency positively and significantly affects the governance performance of state universities at Universitas Negeri Gorontalo; (2) The t-count value for accountability is 2,811 with a significance value lower than the probability value of 0.05 . This means that accountability positively and significantly affects the governance performance of state universities at Universitas Negeri Gorontalo; (3) The t-count value for responsibility is 3.757 with a significance value lower than the probability value of 0.05 . Hence, responsibility positively and significantly affects the governance performance of state universities at Universitas Negeri Gorontalo; (4) The t-count value for independency is 3.548 with a significance value lower than the probability value of 0.05 . So, independency positively and significantly affects the governance performance of state universities at Universitas Negeri Gorontalo; (5) The t-count value for fairness is 2.575 with a significance value lower than the probability value of 0.05 . In other words, fairness positively and significantly affects the governance performance of state universities at Universitas Negeri Gorontalo.

\subsection{Simultaneous Test}

The simultaneous effect is the overall effect of independent variables on the dependent variable. The results are perceptible in the following table:

Table 2. The Result of Simultaneous Parameters

\begin{tabular}{|c|c|c|c|c|c|c|}
\hline \multicolumn{2}{|l|}{ Model } & Sum of Squares & df & Mean Square & F & Sig. \\
\hline \multirow{3}{*}{1} & Regression & 10724.639 & 5 & 2144.928 & 97.607 & $.000^{\mathrm{b}}$ \\
\cline { 2 - 7 } & Residual & 1977.768 & 90 & 21.975 & & \\
\cline { 2 - 7 } & Total & 12702.406 & 95 & & & \\
\hline
\end{tabular}

Source: Data Processed by SPSS 21, 2020

The result F-test in the table above indicates that the F-count value obtained is 97.607 with a probability value of 0.000 or lower than 0.05 . In brief, the hypothesis Ha is accepted, which means that transparency, accountability, responsibility, independency, and fairness simultaneously have a positive and significant effect on the governance performance of state universities at Universitas Negeri Gorontalo. 


\subsection{The Coefficient of Determination}

The coefficient of determination test result is displayed in table 3 below:

Table 3. Coefficient of Determination

\begin{tabular}{|c|c|c|c|c|}
\hline Model & $\mathbf{R}$ & R Square & Adjusted R Square & $\begin{array}{c}\text { Std. Error of the } \\
\text { Estimate }\end{array}$ \\
\hline 1 & $.919^{\mathrm{a}}$ & .844 & .836 & 4.68777 \\
\hline
\end{tabular}

Source: Data Processed by SPSS 21, 2020

The analysis result of the coefficient of determination in the previous table indicated that the value of the coefficient of determination or $\mathrm{R}$ Square is 0,844 . This value denotes that $84,40 \%$ of the governance performance of state universities at Universitas Negeri Gorontalo can be explained by transparency, accountability, responsibility, independency, and fairness. In comparison, the remaining $15,60 \%$ can be explained by other variables not examined in this research, such as organizational commitment, availability of financial resources, and leadership. Furthermore, the partial coefficient test is performed. The test results for the coefficient of partial determination are described in the following table:

Table 4. Coefficient of Partial Determination

\begin{tabular}{|c|c|c|c|c|}
\hline \multirow{2}{*}{ Model } & \multirow{2}{*}{$\begin{array}{c}\text { Standardized } \\
\text { Coefficients }\end{array}$} & \multirow{2}{*}{ Correlation } & \multicolumn{2}{|c|}{ Determination } \\
\cline { 4 - 5 } & 0.156 & 0.782 & 0.122 & Value \\
\hline Transparency & 0.259 & 0.861 & 0.223 & $22.30 \%$ \\
\hline Accountability & 0.320 & 0.857 & 0.275 & $27.50 \%$ \\
\hline Responsibility & 0.205 & 0.726 & 0.148 & $14.80 \%$ \\
\hline Independency & 0.130 & 0.585 & 0.076 & $7.60 \%$ \\
\hline Fairness & \multicolumn{2}{|l}{ Simultaneous Determination Coefficient } & 0.844 & $84.40 \%$ \\
\hline
\end{tabular}

Source: Data Processed by SPSS 21, 2020

The analysis results of the coefficient of determination above disclose that the variable that has the most dominant influence on the governance performance of state universities at Universitas Negeri Gorontalo is responsibility for $27.50 \%$, while the lowest one is fairness for $7.60 \%$.

\section{Discussion}

Universitas Negeri Gorontalo (State University of Gorontalo), abbreviated as UNG, carries out transparency by providing timely, adequate, clear, accurate, and comparable information that is easily accessible by stakeholders according to their rights. The transparency principle adopted by UNG does not reduce the obligation to comply with the provisions of university confidentiality in accordance with statutory regulations, job secrecy, and personal rights. On the one hand, UNG carries out accountability by specifying the details of the duties and responsibilities of each organizational unit and all employees clearly and in line with the vision, mission, key performance indicators of the university. UNG believes that all university organizations, lecturers and, employees have competence according to their duties, 
responsibilities, and roles in implementing good governance. Additionally, UNG has ensured that there is an effective internal control system in managing the university, both academically and financially. Most importantly, Universitas Negeri Gorontalo (UNG) has performance measurements for all levels consistent with the university 's values, the university's key performance indicators, and has a system of rewards and sanctions.

Meanwhile, accountability is realized in submitting annual and semi-annual financial statements to the public, which is done through mass media (print media) that have a broad reach. UNG has carried out social responsibility, such as caring for the community and environmental sustainability, especially around the campus, by planning and implementing an environmentally friendly campus or eco campus. Whereas independency is manifested in each work unit at UNG by avoiding domination by any party, not being influenced by certain interests, free from conflicts of interest, and any influence or pressure so that decisions can be made objectively. Each work unit at UNG has carried out its functions and duties according to the articles of association and legislation, not dominating each other and or shifting responsibilities to one another so that an effective internal control system is achieved.

Furthermore, equality and fairness are observable from the relationship of lecturers and employees that is continuously maintained. The fairness at UNG is undertaken by avoiding discriminatory practices, including respecting the human rights of lecturers and employees, providing equal opportunities regardless of age, ethnicity, race, religion, and gender, treating employees as valuable resources through the means of a knowledge-based management system. In ensuring fairness in the implementation and remuneration system, it is essential to establish a mechanism related to the determination of rewards and punishments for all lecturers and employees. Additionally, UNG can periodically conduct surveys on remuneration levels at other universities as remuneration evaluation material for lecturers and employees. In ascertaining fairness of prices in procuring goods and services, UNG offers an electronic auction service for the sale and procurement of goods between companies or organizations called e-auction as the cornerstone for the formation of e-procurement. Further, e-auction creates transparency, accountability, and efficiency in the implementation of the auction.

In carrying out its activities, UNG always considers the interests of stakeholders based on the principles of equality and fairness. UNG has provided an opportunity for stakeholders to provide input and express opinions for the benefit of the university as well as open access to information under the principle of transparency within the scope of their respective positions.

This present study has been carried out following the rules of scientific writing as it should be. Furthermore, it is strengthened by verification in the field of the data obtained and processed quantitatively. Therefore, it can be concluded that the Principles of Good University Governance consisting of Transparency, accountability, responsibility, independency, and fairness positively affect the governance performance of state universities in Indonesia.

\section{Acknowledgments}

The author would like to thank the lecturers of Universitas Negeri Gorontalo who have helped contribute to the completion of the article. 


\section{References}

Abdul, A. J., \& Adam, M. (2018). Penguatan Tata Kelola Kelembagaan Iain Menuju Iain Ambon Bermutu Melalui Pelaksanaan Good University Governance. Tahkim, 14(2), 22-35. https://doi.org/10.33477/thk.v14i2.630

Aghion, P., Dewatripont, M., Hoxby, C., Mas-Colell, A., \& Sapir, A. (2010). The governance and performance of universities: Evidence from Europe and the US. Economic Policy, 25(61), 7-59. https://doi.org/10.1111/j.1468-0327.2009.00238.x

Akmaliyah, M. (2013). A Review of Experimental and Ex Post Facto Research Designs. Journal of Chemical Information and Modeling, 53(9), 1689-1699.

Ansari, B. I., \& AG, B. (2019). Pengembangan Kinerja Perguruan Tinggi Melalui Manajemen Berbasis Institusi (Studi Kasus pada Perguruan Tinggi Swasta di Lingkungan LLDikti 13 Aceh). Jurnal Serambi Ilmu, 20(2), 174. https://doi.org/10.32672/si.v20i2.1452

Arifudin, O. (2019). Manajemen Sistem Penjaminan Mutu Internal (SPMI) Sebagai Upaya Meningkatkan Mutu Perguruan Tinggi. Jurnal Ilmiah MEA (Manajemen, Ekonomi, \& Akuntansi) , 3(1), 161-169. https://doi.org/10.31955/mea.vol3.iss1.pp161-169

Belgaroui, R., \& Hamad, S. B. (2021). The Good Practices of Academic Autonomy as Mechanism of Governance and Performance of Higher Education Institutions: Case of the University of Sfax. International Journal of English Literature and Social Sciences, 6(1), 177-184. https://doi.org/10.22161/ijels.61.20

Darmawan, D. (2019). Accountability and Transparency: Application of Good Educational Governance. International Journal Management Science and Business, 1(1), 1. https://doi.org/10.17509/msb.v1i1.17108

Delgado, L. (2014). Good Governance in Higher Education . The Right to Education Good. In Research gate (Issue November 2012).

Irianto, S. (2012). Otonomi perguruan tinggi: suatu keniscayaan. Yayasan Pustaka Obor Indonesia.

https://books.google.com/books?hl=en\&lr=\&id=nC9cDAAAQBAJ\&oi=fnd \&pg=PA3\&dq=p artisipasi+masyarakat+dan+pelayanan+holistik+integratif\&ots=WBdSpRTR3w\&sig=MqyJ_ 7Rn_7BCSHM-ny0BCSIJJX8

Jongbloed, B., Vossensteyn, H., \& Vught, F. A. Van. (2018). Transparency in Higher Education: The Emergence of a New Perspective on Higher Education Governance. In European Higher Education Area: The Impact of Past and Future Policies (Issue July, pp. 441-454). https://doi.org/10.1007/978-3-319-77407-7

Julius, D. J., \& Tierney, W. G. (2000). The Responsive University: Restructuring for High Performance. The Journal of Higher Education, 71(3), 373. https://doi.org/10.2307/2649298

Lokuwaduge, C. D. S., \& Armstrong, A. (2015). The impact of governance on the performance of the higher education sector in Australia. Educational Management 
Administration and Leadership, 43(5), 811-827. https://doi.org/10.1177/1741143214535740

Mahmoud, I., Alshaer, A., Al Hila, A. A., Al Shobaki, M. J., \& Naser, S. S. A. (2017). Governance of Public Universities and Their Role in Promoting Partnership with Non-Governmental Institutions. International Journal of Engineering and Information Systems (IJEAIS), 1(9), 214-238. https://ssrn.com/abstract=3084559www.ijeais.org

Matei, L., \& Iwinska, J. (2014). University Autonomy-A Practical Handbook. Central European University. Higher Education Observatory.

Muhsin, Martono, S., Nurkhin, A., Pramusinto, H., Afsari, N., \& Arham, A. F. (2020). The relationship of good university governance and student satisfaction. International Journal of Higher Education, 19(1), 1. https://doi.org/10.5430/ijhe.v9n1p1

Nandi, E. (2021). Governance, Performance and Quality in Higher Education: Evidences from a Case Study. Contemporary Education Dialogue. https://doi.org/10.1177/09731849211056380

Nisar, M. A. (2015). Higher education governance and performance based funding as an ecology of games. Higher Education, 69(2), 289-302. https://doi.org/10.1007/s10734-014-9775-4

Nurhikmayanti, D. (2017). Implementasi Tata Kelola Layanan Publik Untuk Mewujudkan Good Governance Pada Perguruan Tinggi. Jurnal Manajemen Dan Supervisi Pendidikan, 2(1), 24-32. https://doi.org/10.17977/um025v2i12017p024

Reschiwati, Pratiwi, W., Suratman, A., \& Ibrahim, I. M. (2021). Implementation of Good University Governance in Private Higher Education Institutions in Indonesia. Journal of Southwest Jiaotong University, 56(3), 295-306. https://doi.org/10.35741/issn.0258-2724.56.3.25

Rulyanti Susi Wardhani, Taufik Taufik, Luk luk Fuadah, \& Saadah Siddik. (2019). The Implementation of Good University Governance in State Universities. Jurnal Organisasi Dan Manajemen, 15(1), 16-23. https://doi.org/10.33830/jom.v15i1.6.2019

Sagara, Y., \& Yustini, S. (2019). Studi Fenomenologis Tentang Implementasi Tata Kelola Perguruan Tinggi Badan Hukum di Indonesia. Akuntabilitas, 12(2), 249-258. https://doi.org/10.15408/akt.v12i2.13226

Sayidah, N., Ady, S. U., Supriyati, J., Sutarmin, Winedar, M., Mulyaningtyas, A., \& Assagaf, A. (2019). Quality and university governance in Indonesia. International Journal of Higher Education, 8(4), 10-17. https://doi.org/10.5430/ijhe.v8n4p10

Siambi, J. K. (2021). A Review of Strategic Planning and Implementation in Universities in Jeddah, Saudi Arabia. International Education and Research Journal, 7(1), 42-48. https://www.researchgate.net/publication/349236884

Silvernail, K. D., Graso, M., Salvador, R. O., \& Miller, J. K. (2021). Perceived fairness of faculty governance: a study of 51 countries. Higher Education, 82(3), 615-633. 
https://doi.org/10.1007/s10734-021-00708-5

Sternberg, R. J. (2007). Rethinking' university admission for the 21 st century. Perspectives in Education, 25(4), 7-16.

Sugiyono. (2014). Educational Research Methods Quantitative, Qualitative Approach and R\&D. In Bandung: Alfabeta.-Bing. Bandung: Alfabeta. https://scholar.google.com/citations?view_op=view_citation\&hl=en\&user=uUIIujUAAAAJ \&sortby=pubdate\&citation_for_view=uUIIujUAAAAJ:hFOr9nPyWt4C

Suyahman. (2016). Implementation of Multicultural Education in Indonesia Between Expectations and Reality. The 2nd International Conference on Science, Technology, and Humanity, 202-215.

Wahyudin, A., Nurkhin, A., \& Kiswanto, K. (2017). Hubungan Good University Governance Terhadap Kinerja Manajemen Keuangan Perguruan Tinggi. Jurnal Keuangan Dan Perbankan, 21(1), 60-69. https://doi.org/10.26905/jkdp.v21i1.1227

\section{Copyright Disclaimer}

Copyright for this article is retained by the author(s), with first publication rights granted to the journal.

This is an open-access article distributed under the terms and conditions of the Creative Commons Attribution license (http://creativecommons.org/licenses/by/4.0/). 